\title{
BEBERAPA GEJALA BAHASA DALAM BAHASA INDONESIA
}

\author{
Dra. Henilia, M.Hum \\ Universitas Amir Hamzah \\ Henilia87@yahoo.co.id
}

\begin{abstract}
Abstrak
Bahasa adalah alat komunikasi yang memegang peranan penting dalam kehidupan manusia. Penguasaan terhadap suatu bahasa bukanlah merupakan warisan atau turunan melainkan sesuatu yang diperoleh dari kebiasaan dalam kehidupan. Bahasa Indonesia merupakan bahasa yang hidup dan berkembang ejalan dengan perkembangan dengan masyarkat Indonesia (pemakai bahasa). Sehubungan dengan perkembangan itulah kita jumpai gejala yang timbul diantaranya perubahan bentuk kata maupun perubahan arti kata, perubahan-perubahan ini ada yang sudah diterima dan ada yang belum diterima sebagai bahasa yang umum. Gejala bahasa ini adalah salah satu faktor yang tidak bisa diabaikan begitu saja. Gejala bahasa yang dibicarakan adalah gejala bahasa hiperkorek, gejala bahasa pleonasme, gejala bahasa kontaminasi, gejala bahasa protesis, gejala bahasa epentesis. Masing-masing gejala bahasa tampaknya mempunyai khusus secara sendiri-sendiri. Pengetahuan gejala bahasa dapat menunjang sikap serta pengertian yang wajar terhadap bahasa Indonesia. Bahasa Indonesia tidak mengenal gejala concord. Peran positif dalam gejala bahasa adalah menyumbangkan sejumlah bentuk yang menambah khazanah kata dalam bahasa Indonesia yaitu gejala bahasa adaptasi, peranan negative secara umum memberi gambaran bahwa gejala bahasa Indonesia menunjukkan bentuk-bentuk yang salah atau destandarisasi yaitu gejala bahasa hiperkorek, gejala bahasa kontaminasi, dan gejala bahasa pleonasme.
\end{abstract}

\section{Keyword : Beberapa Gejala Bahasa, Bahasa Indonesia.}

\section{PENDAHULUAN}

Bahasa adalah alat komunikasi yang memegang peranan penting dalam kehidupan manusia. Penguasaan terhadap suatu bahasa bukanlah merupakan warisan atau keturunan melainkan sesuatu yang diperoleh dari kebiasaan dalam 
kehidupan. Dalam kegiatan sehari-hari, banyak orang menganggap, bahwa bahasa tidak perlu mendapat perhatian khusus sesuai dengan fungsinya dalam masyarakat. Anggapan ini salah, karena bahasa merupakan bahagian daripada kebudayaan. Bahasa mempunyai dua aspek mendasar, yaitu bentuk, baik bunyi dan tulisan maupun fungsional dan strukturnya, serta makna. Jika kita perhatikan bahasa dengan terperinci dan teliti, kita melihat bahwa bahasa itu dalam bentuk dan maknanya menunjukan perbedaan-perbedaan kecil-besar antara pengungkapannya yang satu dengan pengungkapan yang lain, lalu kita akan mendengar perbedaan-perbedaan, umpamanya antara satuan bunyi /a/ yang diucapkan seseorang dengan waktu yang satu ke waktu yang lain.

Amatlah sulit atau mustahil bahwa bunyi atau lafal suatu satuan bunyi, suatu kata atau kalimat betul-betul berbunyi yang sama benar. Oleh karena pendengaran kita secara jasmani dipengaruhi oleh banyak faktor seperti udara, kesegaran perasaan dan besar perhatian kita, maka bentuk-bentuk bunyi itu dapat kita bedakan. Begitu juga gejala bahasa dalam masalah kebahasaan yang memberi peranan positif dan peranan negatif.

Peranan positif dalam gejala bahasa adalah menyumbangkan sejumlah bentuk yang menambah khazanah kata dalam bahasa Indonesia, yaitu gejala bahasa Adaptasi. Kemudian peranan negatif secara umum memberi gambaran bahwa gejala bahasa Indonesia menunjukan bentuk-bentuk yang salah atau destandarisasi yaitu gejala bahasa Hiperkorek, gejala bahasa Kontaminasi, gejala bahasa Pleonasme, gejala bahasa protesis, dan gejala bahasa epentesis atau masagose. Gejala bahasa adalah salah satu faktor yang tidak bisa diabaikan begitu saja, tetapi mungkin tidak pernah terpikirkan oleh kita, bahwa ada hal yang perlu diperhatikan dalam masalah gejala bahasa ini.

\section{KAJIAN PUSTAKA}

\section{A. Pengertian Gejala Bahasa}

Bahasa Indonesia merupakan bahasa yang hidup dan berkembang sejalan dengan perkembangan masyarakat Indonesia (pemakai bahasa). Sehubungan dengan perkembangan itulah kita jumpai gejala yang timbul diantaranya perubahan bentuk kata maupun perubahan arti kata. Perubahan-perubahan ini ada yang sudah diterima, ada yang belum diterima sebagai bahan yang umum.

Beberapa pengertian mengenai gejala bahasa, khususnya dalam bahasa Indonesia yang merupakan pendapat dari beberapa sarjana bahasa Indonesia akan ditampilkan di bawah ini untuk membuka jalan ke arah pembicaraan yang lebih khusus mengenai gejala bahasa.

["... J. S. Badudu (1986 : 47) mengatakan gejala bahasa ialah peristiwa yang menyangkut bentukan-bentukan kata atau kalimat dengan segala macam prosesnya ..."] 
[".. Asis Safioedin, S. H (1980 : 163) mengatakan timbulnya gejala bahasa disebabkan oleh pemakaian fonem yang mengalami berbagai gejala : perubahan, penambahan, penghilangan, perubahan tempat atau penggantian letak ..."]

["... Suwardi Notosudirjo (1979: 67) mengatakan yang dibicarakan dalam gejala bahasa ialah perubahan fonem-fonem pada suatu kata, tetapi pada umumnya tidak mengubah arti kata itu. Perubahan fonem-fonem itu dapat berupa penambahan, pengurangan, atau penghilangan fonem. Atau penggantian fonem yang berhubungan dengan ilmu fonetik untuk memudahkan ucapan ..."]

Berdasarkan pendapat para sarjana tampak mempunyai kesamaan, sama-sama membicarakan perubahan yang terjadi pada suatu kata. Tapi ketiga pendapat itu masih berada pada batas kata, tidak menyinggung kalimat. Seperti halnya pendapat pertama di atas.

\subsection{Pengertian Gejala Bahasa Hiperkorek}

Hiperkorek (Inggris : hypercorrect) yang artinya 'terlalu tepat' atau 'terlalu betul', yang sudah betul dibetulkan lagi akhirnya salah. Gejala bahasa hiperkorek selalu menunjukan sesuatu yang salah, baik salah ucapan maupun kesalahan tulisan atau ejaan.

contoh :

$\begin{array}{ll}\text { betul } & \text { hiperkorek } \\ \text { insaf } & \text { insyaf } \\ \text { sah } & \text { syah } \\ \text { surga } & \text { syurga } \\ \text { topan } & \text { taufan } \\ \text { sentosa } & \text { sentausa } \\ \text { asas } & \text { azas } \\ \text { kuitansi } & \text { kwitansi } \\ \text { mantra mentera } & \\ \text { manajer } & \text { manager }\end{array}$

Kata-kata insaf, sah, topan, sentosa, asas, kuitansi, mantra, manajer dijadikan orang menjadi insyaf, syah, syurga, taufan, sentausa, azas, kwitansi, mentera, manager karena orang menganalogikan dengan kata-kata seperti tobat, torat, topan yang terdapat dalam bahasa Arab yaitu taubat, taurat, taufan, tetapi ke dalam bahasa Indonesia kata-kata ini disandihkan : au menjadi o, sehingga kata-kata ini tobat, torat, topan. Bertolak dari sini orang mengira bahwa katakata tersebut di atas sama asal dan bentuknya sehingga timbul hiperkorek. Demikian juga dengan kata surga (berasal dari bahasa sanskerta) menjadi syurga, mungkin orang mengira bahwa kata itu berasal dari bahasa Arab. Katakata bahasa Arab yang ditulis dengan huruf sin, shad, tsa dialihkan ke dalam bahasa Indonesia dengan huruf s saja, kemudian di syin menjadi sy dalam bahasa Indonesia. Seperti : kata-kata insaf, sah, dalam bahasa Arab kata-kata itu mempunyai unsur bunyi shad (yang menjadi s dalam bahasa Indonesia oleh sebab itu tidak dituliskan insyaf, syah karena menjadi hiperkorek. Begitu juga kata asas ditulis dengan huruf sin dalam bahasa Arab. Oleh sebab itu apabila azas jelas hiperkorek. Gejala bahasa Hiperkorek pada umumnya terjadi pada 
kata-kata pungut. Anggapan yang salah terhadap bentuk kata-kata pungut itu mengakibatkan timbulnya hiperkorek.

\subsection{Timbulnya Gejala Bahasa Pleonasme}

Faktor penyebab timbulnya gejala bahasa pleonasme itu ada empat, yaitu :

1. Faktor ketidak tahuan.

2. Faktor ketidak sengajaan.

3. Faktor kesengajaan dengan tujuan penekanan makna atau arti.

4. Faktor peniruan bentuk (concord) yang terdapat pada bahasa asing yang mempunyai pengaruh besar terhadap bahasa Indonesia.

Berdasarkan pendapat J. S. Badudu tentang faktor penyebab gejala bahasa pleonasme, dikemukakan adanya concord (persesuaian bentuk) yang terdapat pada bahasa Inggris, bahasa Arab, bahasa Belanda, dan bahasa Perancis. Kita sudah mengetahui bahwa keempat bahasa ini mempunyai pengaruh besar terhadap bahasa Indonesia. Tentunya pengaruh itu tidak hanya mencakup masalah kosa kata saja. Tetapi tata bahasa pun turut diambil bagian walaupun bahasa Indonesia telah memiliki kaidah-kaidah tata bahasa sendiri.

Persesuaian bentuk atau concord dalam bahasa Inggris, bahasa Arab, bahasa Belanda, dan bahasa Perancis ditemui contoh sebagai berikut :

Kata benda dalam bahasa Indonesia tidak mengenal bentuk khusus

Untuk menyatakan jenis kelamin kata (gender) baik untuk maskulin maupun feminim, wujud katanya tidak berubah

contoh :

1. kata / singa / dapat dipakai untuk pengertian jantan dan betina

2. kata / saudara / dapat dipakai untuk pengertian laki laki dan perempuan/wanita.

Akibat pengaruh bahasa sansekerta dan bahasa Arab dijumpai bentuk yang membedakan jenis kelamin kata :

$\begin{array}{ll}\text { maskulin } & \text { feminism } \\ \text { saudara } & \text { saudari } \\ \text { pragawan } & \text { pragawati } \\ \text { mahasiswa } & \text { mahasiswi } \\ \text { hadirin } & \text { hadirat } \\ \text { muslimin } & \text { muslimat } \\ \text { Mukminin } & \text { mukminat }\end{array}$

Bentuk-bentuk tersebut bukanlah bentuk yang gramatikal. Kata benda tidak mengenal jamak tunggal. Kata benda dalam bahasa Indonesia tidak mengenal khusus untuk membedakan jamak (mufrad) dan tunggal (singular)

contoh : ia membeli dua ekor ayam

saya membeli seekor ayam

seorang anak pun tak ada

Bahasa Inggris

kelihatan empat orang anak

contoh : one child (seorang anak)

five children (lima orang anak)

Jurnal Insitusi Politeknik Ganesha Medan

Juripol, Volume 4 Nomor 1 Maret 2021 
Bahasa Belanda

contoh : een kipdrie kippen

een oortweeogen

Bahasa Arab

een kind vijf kinderen

contoh :

Al waladu Sagirun (anak laki-laki itu kecil)

Al waladani Sagirani (dua orang anak laki-laki kecil)

Dalam bahasa Indonesia tidak mengenal perubahaan kata kerja untuk membedakan waktu

Bahasa Indonesia $\quad \underline{\text { Bahasa Inggris }}$

pergi

sedang pergi going

telah pergi gone

Dari contoh di atas terlihat untuk menyatakan jamak terjadi pada kata benda seperti yang telah dikatakan bahwa bahasa Inggris, bahasa Arab, bahasa Belanda, dan bahasa Perancis mempunyai pengaruh yang besar terhadap bahasa Indonesia, maka tentu pula persesuaian bentuk ini akan ditiru oleh pemakai bahasa Indonesia. Sehingga timbul bentuk-bentuk pleonasme

\section{Kesimpulan}

\section{KESIMPULAN}

1. Gejala bahasa sebagai suatu peristiwa yang menyangkut bentukan-bentukan kata atau kalimat dengan segala macam prosesnya, dapat dikatakan pula sebagai salah satu alat atau cara pencatatan perubahan-perubahan kata.

2. Masing-masing gejala bahasa tampaknya mempunyai kasus secara sendirisendiri. Pengetahauan gejala bahasa dapat menunjang sikap serta pengertian yang wajar terhadap bahasa Indonesia.

3. Bahasa Indonesia tidak mengenal gejala concord.

4. Pengadaptasian memiliki peranan yang sangat penting dan menambah perbendaharaan kata dalam bahasa Indonesia.

\section{Saran}

1. Melihat kedudukan gejala bahasa dalam bahasa Indonesia, perlu diperhatikan mendapat perhatian yang wajar pada lembaga pendidikan formal.

2. Masyarakat pemakai bahasa harus memperhatikan kaidah-kaidah dalam bahasa Indonesia, agar tidak terjadi kesalahan-kesalahan dalam menulis dan berbicara. 


\section{REFERENCES}

Samin Siregar, Ahmad. 1994. Bahasa Indonesia Untuk Perguruan Tinggi. Medan:

Fakultas Sastra USU.

Badudu, Dr. Ys. 1978. Pelik-Pelik Bahasa Indonesia. Bandung: Pustaka Prima.

Keraf, Gorys, Drs. 1995. Tata Bahasa Iindonesia, Cetakan II. Ende Flores: Nusa Indah.

Notosudirjo, Suwardi. 1979. Pengetahuan Bahasa Indonesia (baru). Jakarta: Mutiara.

Safiodin, Asis. S.H. 1980. Membina bahasa Indonesia. Bandung: Alumni.

Pedoman Umum Ejaan Bahasa Indonesia Yang Disempurnakan. Pusat Pembinaan Dan Pengembangan Bahasa Departemen Pendidikan Dan Kebudayaan Republik Indonesia.

Halim, Amran (ed). Politik Bahasa Nasional, buku II. Pusat Pembinaan dan Pengembangan Bahasa, Jakarta. 